\title{
Characterization of Dehydrin protein, CdDHN4-L and CdDHN4-S, and their differential protective roles against abiotic stress in vitro
}

\author{
Aimin Lv', Liantai Su ${ }^{1}$, Xingchen Liu', Qiang Xing ${ }^{3}$, Bingru Huang ${ }^{4}$, Yuan $\mathrm{An}^{1,2^{*}}$ and Peng Zhou ${ }^{1^{*}}$
}

\begin{abstract}
Background: Dehydrins play positive roles in regulating plant abiotic stress responses. The objective of this study was to characterize two dehydrin genes, CdDHN4-L and CdDHN4-S, generated by alternative splicing of CdDHN4 in bermudagrass.

Results: Overexpression of CdDHN4-L with $\varphi$-segment and CdDHN4-S lacking of $\varphi$-segment in Arabidopsis significantly increased tolerance against abiotic stresses. The growth phenotype of Arabidopsis exposed to $\mathrm{NaCl}$ at $100 \mathrm{mM}$ was better in plants overexpressing CdDHN4-L than those overexpressing CdDHN4-S, as well as better in $E$. coli cells overexpressing CdDHN4-L than those overexpressing CdDHN4-S in 300 and $400 \mathrm{mM} \mathrm{NaCl}$, and under extreme temperature conditions at $-20{ }^{\circ} \mathrm{C}$ and $50{ }^{\circ} \mathrm{C}$. The $\mathrm{CdDHN} 4-\mathrm{L}$ had higher disordered characterization on structures than CdDHN4-S at temperatures from 10 to $90^{\circ} \mathrm{C}$. The recovery activities of lactic dehydrogenase (LDH) and alcohol dehydrogenase (ADH) in presence of CdDHN4-L and CdDHN4-S were higher than that of LDH and $\mathrm{ADH}$ alone under freeze-thaw damage and heat. Protein-binding and bimolecular fluorescence complementation showed that both proteins could bind to proteins with positive isoelectric point via electrostatic forces.

Conclusions: These results indicate that CdDHN4-L has higher protective ability against abiotic stresses due to its higher flexible unfolded structure and thermostability in comparison with CdDHN4-S. These provided direct evidence of the function of the $\varphi$-segment in dehydrins for protecting plants against abiotic stress and to show the electrostatic interaction between dehydrins and client proteins.
\end{abstract}

Keywords: Abiotic stress, Dehydrin, Intrinsic disorder protein, Molecular chaperone, Protein interaction, $\varphi$-Segment

\section{Background}

Dehydrins (DHNs) are late embryogenesis abundant (LEA) II proteins, which are thermostable and can maintain their integrity at boiling temperature, playing crucial roles in protecting plants against abiotic stresses such as extreme temperature, drought, and salinity stress $[1,2]$. Dehydrin can protect nucleic acids in plant cells during seed maturation and stress responses by interacting electrostatically with vesicles of both zwitterionic and negatively charged phospholipids [3]. Many studies have

\footnotetext{
* Correspondence: anyuan@sjtu.edu.cn; pzhou0063@sjtu.edu.cn ${ }^{1}$ School of Agriculture and Biology, Shanghai Jiao Tong University, Shanghai 200240, People's Republic of China

Full list of author information is available at the end of the article
}

reported that dehydrins may play a protective function on enzymes or phospholipids as molecular chaperone [4] or molecular shield [5]. Dehydrin ERD10 and ERD14 have chaperone activities with rather wide substrate specificity and interact with phospholipid vesicles through electrostatic forces under cold stress [6], while dehydrin $P p D H N A$ and PpDHNB from Physcomitrella patens provide protection as molecular shields to lactate dehydrogenase (LDH) under osmotic and freezing conditions [7]. KS-type dehydrin (AtHIRD11) can recover the LDH activity denatured by $\mathrm{Cu}^{2+}$ in Arabidopsis [8]. Hughes and Graether [9] proposed that the dehydrin would stay preferentially localized near the enzyme rather than bind with LDH. Furthermore, there was an extremely weak 
association between the K-segment of $\mathrm{K}_{2}$ and $\mathrm{LDH}$, which was mediated by long-range electrostatic forces. Kovacs et al. [10] argued that the strict distinction between classical chaperone action and molecular shield activity might not be tenable. Although the protective functions of dehydrins to plants exposed to abiotic stress conditions in vivo or vitro have been reported [11], the protective mechanism is not completely understood.

Dehydrins are believed to have highly flexible structures because they are composed of charged and polar amino acids [3, 12], and are found to belong to intrinsically disordered proteins (IDPs) [2, 13, 14]. IDPs are natively unstructured proteins that lack defined secondary and tertiary structures [12], which can interact with multiple partners (such as proteins, nucleic acids, membrane and metal ion) in protein interaction networks, and provide important advantages in molecular recognition through transient protein-protein interactions [15]. This type of proteins plays crucial roles in physiological and molecular processes of plants and animals, and works as signaling proteins, transcription factors, or stress response proteins [16-18]. The sequence characteristics of dehydrins possess conserved several segments, which include K-, Y- or S-segments. K-segments (EKKGIMDKIKEKLPG or similar sequence) present in each dehydrin, form an amphipathic helix and are required for binding to anionic phospholipid vesicles [3, $6,19]$. Y-segments, with the core sequence DEYGNP, are located in the $\mathrm{N}$-terminal region of many dehydrins. It has significantly high identity with the nucleotide-binding site of plant and bacterial chaperones [20]. S-segments (LHRSGSSSSSSSEDD) are proposed to affect dehydrin's nuclear localization [21]. Many dehydrins also contain less conserved $\phi$-segments, which are enriched with polar amino acids, Gly or a combination of Pro and Ala, and present in one or more copies between the K-segments [19, 22]. These enriched polar residues make DHNs flexible [9]. The $\phi$-segments have a structure of random coil, which may allow the $\phi$-segments to bind substantial amounts of water due to interaction of dipolar peptide bonds with water molecules $[23,24]$. However, how the presence of $\phi$-segments in DHNs may affect stress protection is not clear.

In our previous studies, two dehydrins, CdDHN4-L (accession no. KX243552) and CdDHN4-S (accession no. KX243553), were cloned from bermudagrass (Cynodon dactylon $x$ Cynodon transvaalensis) 'Tifway', which are from RNA alternative splicing with exactly the same genomic DNA sequence [25]. The CdDHN4-L and CdDHN4-S are different in a small protein fragment ${ }^{143}$ QQGHTGVTGSGTGTY ${ }^{158} \mathrm{G}$, namely $\phi$-segment (Fig. 1). Due to the binding function of $\phi$-segment to water molecules $[23,24]$, it was hypothesized that the deletion of $\phi$-segment in CdDHN4-S may make it function differently from CdDHN4-L in plant tolerance to abiotic stresses. Therefore, the objectives of this study were to: 1) compare the structure and functions of the two dehydrin proteins due to a $\phi$-segment deletion; 2) determine the differential mechanisms of the two dehydrin proteins in regulating abiotic stress tolerance (including osmotic, salt, heat or low temperature) in Arabidopsis.
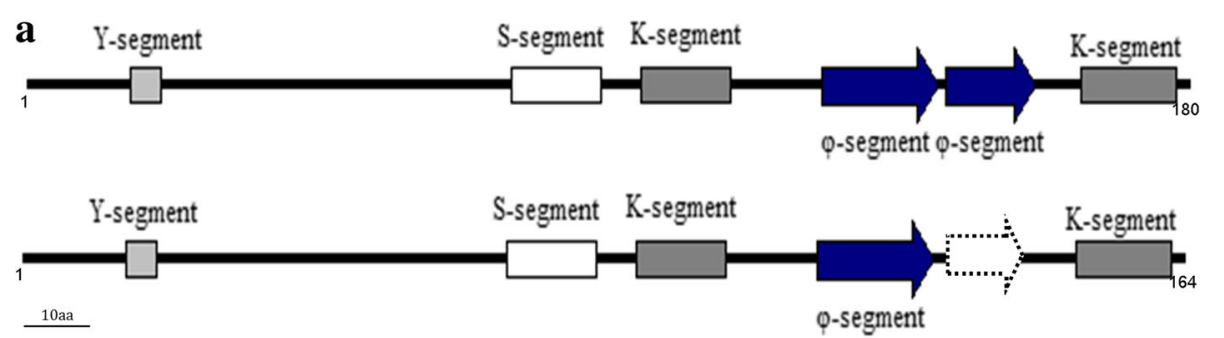

b

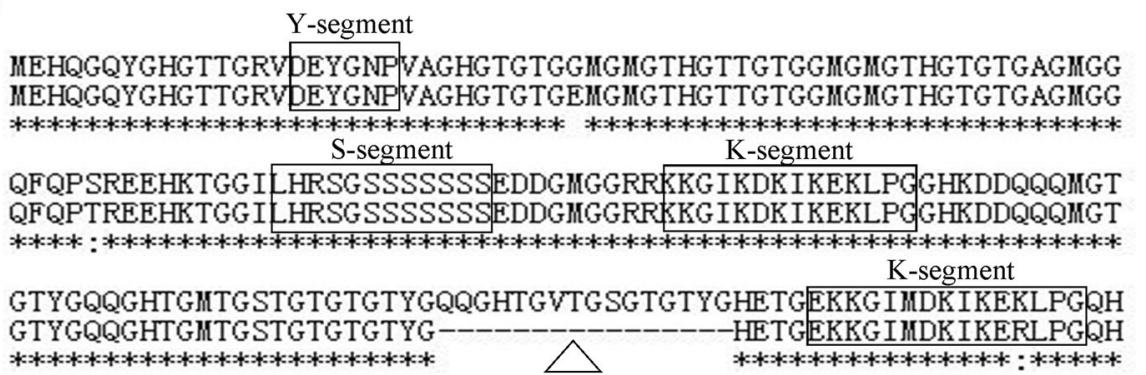

Fig. 1 Schematic representation of dehydrin protein. a Schematic representation of dehydrin contains domains: top, CdDHN4-L; bottom, CdDHN4-S. $\varphi$-segment deletion (white dashed arrows). b The amino acids sequence alignment between CdDHN4-L and CdDHN4-S 


\section{Results}

Expression of CdDHN4-L or CdDHN4-S in plants increased growth rates under abiotic stresses

Transgenic lines with high expression levels of dehydrin genes (Fig. 2b) were used for further investigation. No significant differences were observed in fresh weight, root length (Fig. 2) between wild-type and transgenic Arabidopsis seedlings under control treatments. The root length and fresh weight of Arabidopsis overexpressing CdDHN4-L or CdDHN4-S were significantly higher than wild-type at 10 days of $100 \mathrm{mM}$ sorbitol stress (Fig. 2a). In response to salt treatment, the seed germination rate, root length and fresh weight of Arabidopsis overexpressing CdDHN4-L or CdDHN4-S were significantly higher than that of wild-type Arabidopsis under 50, 75 and $100 \mathrm{mM} \mathrm{NaCl}$ treatment (Fig. 3). Arabidopsis overexpressing CdDHN4-L exhibited better growth status than those overexpressing CdDHN4-S under $100 \mathrm{mM} \mathrm{NaCl}$. E.coli cells harboring CdDHN4-L exhibited significantly higher growth rate than those harboring CdDHN4-S under $\mathrm{NaCl}$ conditions at 300 and $400 \mathrm{mM}$, and under extreme temperature conditions at $-20{ }^{\circ} \mathrm{C}$ and $50{ }^{\circ} \mathrm{C}$ (Fig. $3 \mathrm{c}$ and $\mathrm{d}$ ).

\section{Intrinsic disorder protein character of CdDHN4-L and CdDHN4-S}

The purified CdDHN4-L and CdDHN4-S proteins migrated as larger proteins in the SDS-PAGE analysis, with molecular masses at $25 \mathrm{kDa}$ and $23 \mathrm{kDa}$ for CdDHN4-L and CdDHN4-S, respectively (Fig. 4a). The structure diagnostic analysis showed that CdDHN4-L and CdDHN4-S were hydrolyzed when the ratio of dehydrin protein: trypsin was 1:10, while BSA remained until the ratio was 1:5. The CdDHN4-L and CdDHN4-S proteins were hydrolyzed by low concentration of protease in comparison with BSA (Additional file 1).

Both the CD spectra of the two dehydrin proteins had a large negative peak close to $200 \mathrm{~nm}$ at room temperature, which were typical of IDPs (Fig. 4b). The CdDHN4-L and CdDHN4-S were highly disordered proteins, as seen from analyzing the secondary structures of recombinant proteins by CD Spectra software, in which the disordered structure ratio of CdDHN4-L was 64.6\%, which was higher than that of CdDHN4-S (61.1\%). Other secondary structures such as $\beta$-strand and $\alpha$-helix appeared differently between the two dehydrins.

FTIR gives the amide-I and -II bands between 1,700 and $1,500 \mathrm{~cm}^{-1}$. Both proteins have a shoulder and band at $1640-1645 \mathrm{~cm}^{-1}$, which indicated random coil conformation (Fig. 4c). The second derivative spectra were calculated (Additional file 2). Spectra of CdDHN4-L and CdDHN4-S showed similar profiles: three major bands at $1620,1633 / 1634$ and $1655 \mathrm{~cm}^{-1}$, and four minor bands at 1656, 1666/1667, 1678 and $1693 / 1691 \mathrm{~cm}^{-1}$ in amide-I region. The Spectra were lower in CdDHN4-L than CdDHN4-S. The curve-fitting results of the amide-I region showed that CdDHN4-L had $63.2 \%$ disordered conformation, $11.1 \% \alpha$-helix and $25.8 \% \beta$-sheet, while CdDHN4-S had $62.3 \%$ disordered conformation, $10.4 \% \alpha$-helix and 23.3\% $\beta$-sheet (Additional file 2).
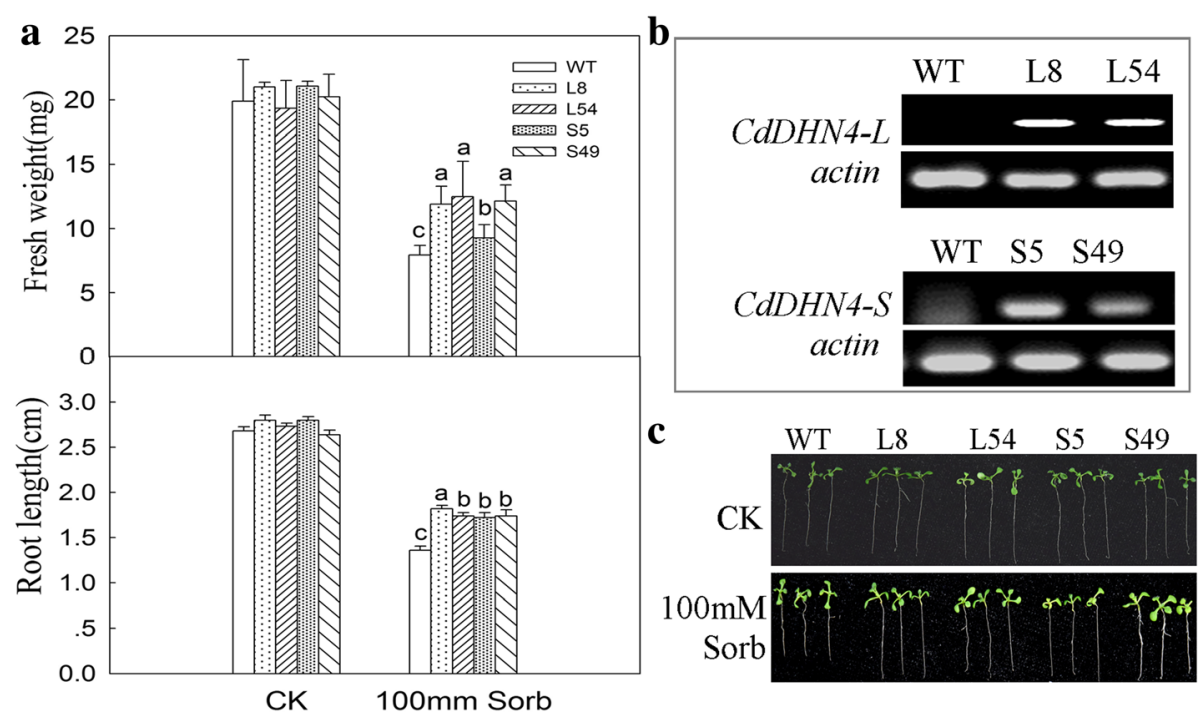

Fig. 2 Phenotype of CdDHN4 transgenic plants under drought stress. a Fresh weight and root length of plant under 0 or $100 \mathrm{mM}$ Sorb for 10 days $(\mathrm{SE}, n=4)$. $\mathbf{b}$ The semi-quantitative of $\mathrm{CdDHN4-L}$ or $\mathrm{CdDHN4-s}$ in 2-week-old wild type and transgenic plants under normal condition. Phenotypes (c), plant under 0 or 100 mM Sorb for 10 days (SE, $n=4$ ). WT-wild type Arabidopsis (Columbia), L8/L54-Arabidopsis overexpressing CdDHN4-L, S5/S49-Arabidopsis overexpressing CDDHN4-S. Fresh weight was calculated as the weight of five seedlings. Data are representative of three independent experiments. Different letters show significant differences $(p<0.05)$ as determined by ANOVA analysis 
a

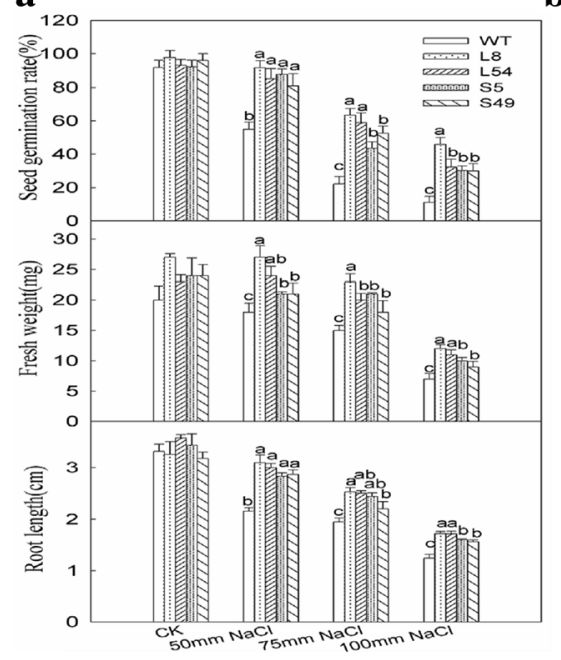

b
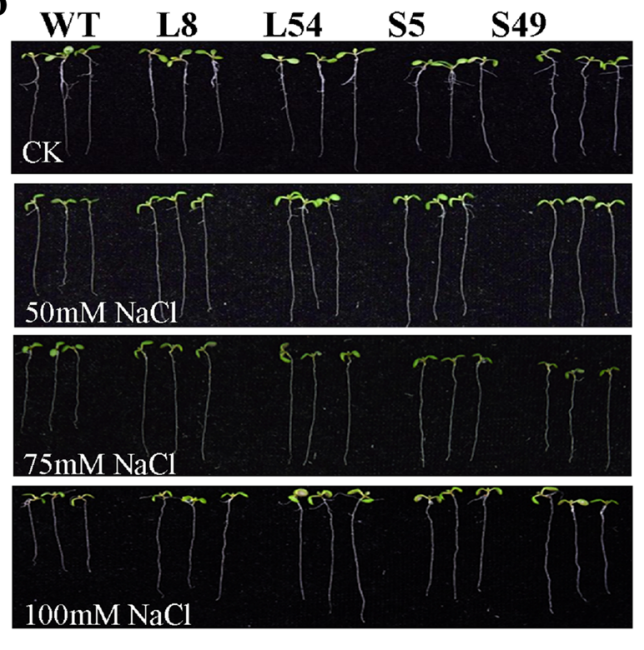

C

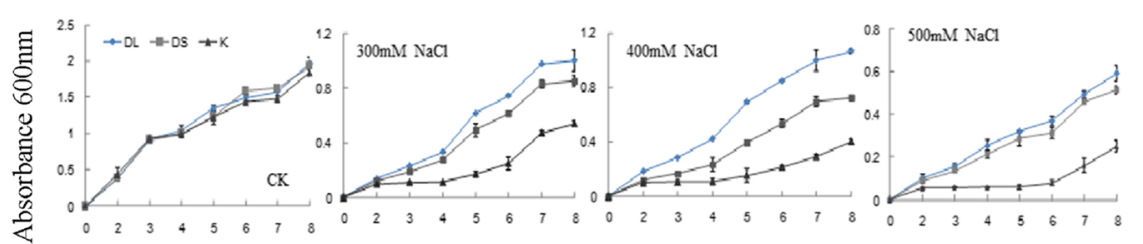

d

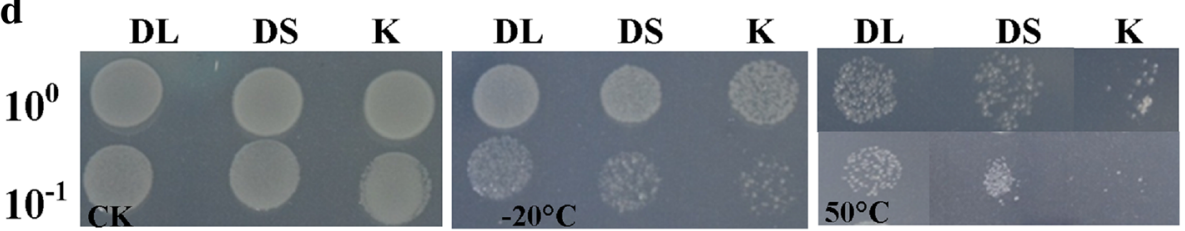

Fig. 3 Phenotype of CdDHN4 transgenic plants under salt stress. Seed germination rate, fresh weight, primary root length (a) and phenotypes (b) of one-week-old plants under 0,50,75, $100 \mathrm{mM} \mathrm{NaCl}$ stress. Seed germination rate was measured after 3 days. Growth of IPTG induced E.coli cultures producing CdDHN4-L (DL), CdDHN4-S (DS) or pET-21a (K) with control or different stress treatment. E.coli Rosetta cells harboring CdDHN4-L, CdDHN4-S or empty vector pET-21a were grown as mentioned above, and diluted to OD $600=0.6$. E.coli cells (600 $\mu$ I) were inoculated in $10 \mathrm{~mL} \mathrm{LB}$ medium and incubated at $30^{\circ} \mathrm{C}$. c For salt stress, the LB medium included five concentrations of $\mathrm{NaCl}(300,400$, and $500 \mathrm{mM}$ ). The bacterial suspension was obtained every hour for growth as described previously (Drira et al., 2015). d For temperature treatments, IPTG induced cultures $\left(\mathrm{OD}_{600}=0.6\right)$ were exposed to $-20^{\circ} \mathrm{C}$ for $2 \mathrm{~h}$ or $50{ }^{\circ} \mathrm{C}$ for $45 \mathrm{~min}$. A $10 \mu \mathrm{L}$ of each sample diluted by 10 -fold was spotted on LB plates, and incubated at $37{ }^{\circ} \mathrm{C}$ for $16 \mathrm{~h}$

\section{Secondary structures of CdDHN4-L and CdDHN4-S protein} at different temperatures

The secondary structures of recombinant CdDHN4-L and CdDHN4-S proteins were analyzed by CD spectroscopy in ultrapure water at temperatures from 10 to $90{ }^{\circ} \mathrm{C}$. The spectra of CdDHN4-L and CdDHN4-S proteins had a strong negative band near $200 \mathrm{~nm}$, and a positive shoulder band near $220 \mathrm{~nm}$ under different temperatures (Fig. 5a and b). The later band indicated that both proteins contained other secondary structures. There was a balance between disordered structure and the other secondary structure under different temperatures, and the equilibrium point was near $206 \mathrm{~nm}$. Moreover, the CD spectroscopy values between $10{ }^{\circ} \mathrm{C}$ and $90{ }^{\circ} \mathrm{C}$ were different between the two proteins, in which the largest value (negative bands) of CdDHN4-L and CdDHN4-S occurred at $197 \mathrm{~nm}$ and $195 \mathrm{~nm}$, respectively (Fig. 5c). The rate of random coil structures of CdDHN4-L and CdDHN4-S at temperatures from 10 to $90{ }^{\circ} \mathrm{C}$ decreased from 76.5 to $61.8 \%$ and 74.4 to $63.2 \%$,respectively, while beta structures were increased by 14 and $3 \%$, respectively, and helical structures of CdDHN4-S increased by $8.2 \%$. The random ratios were higher in CdDHN4-L than in CdDHN4-S from 10 to $30{ }^{\circ} \mathrm{C}$ and from 60 to $90{ }^{\circ} \mathrm{C}$, while the random ratios in $\mathrm{CdDHN} 4-\mathrm{L}$ were higher or similar to CdDHN4-S at $40-50{ }^{\circ} \mathrm{C}$ (Fig. 5d). In addition, the bands of CdDHN4-L and CdDHN4-S proteins were still present at $100{ }^{\circ} \mathrm{C}$ for $10 \mathrm{~min}$, but the band of control (BSA) was disappeared (Fig. 5e). 

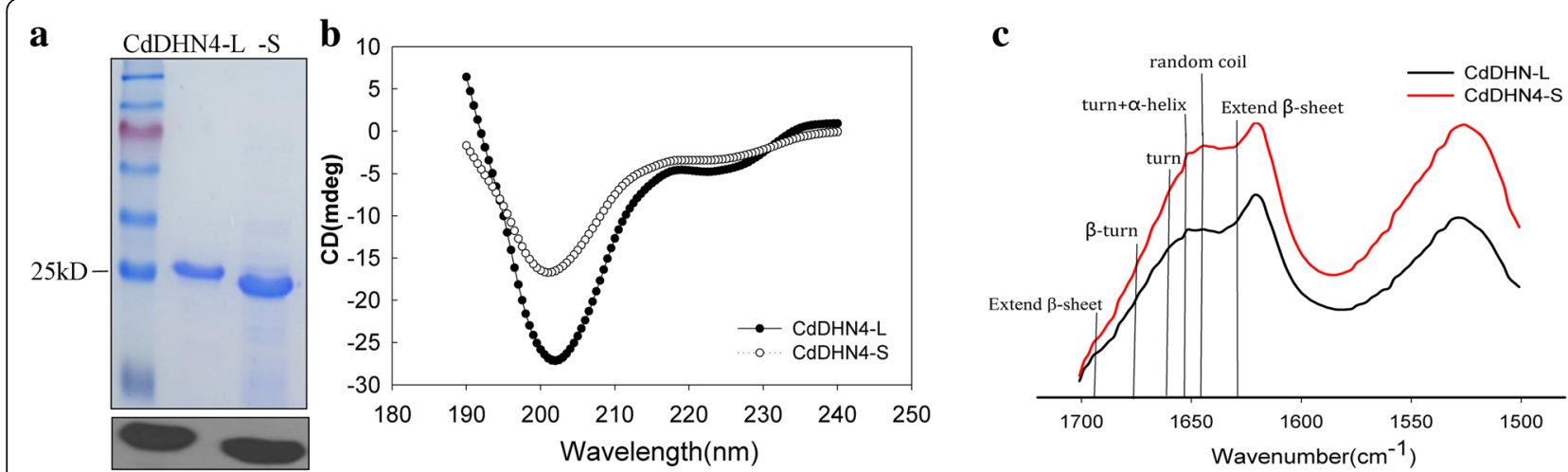

Fig. 4 Intrinsically disordered character of CdDHN4-L and CdDHN4-S. a Purified protein were detected by SDS-PAGE and stained with Coomassie brilliant blue and after were transferred to PVDF membranes and probed with the anti-K segment of DHNs antibody. $\mathbf{b}$ CD spectra of CdDHN4-L and $-\mathrm{S}$ were recorded at the same protein concentration $\left(0.25 \mathrm{mg} \mathrm{mL}^{-1}\right)$ in deionized water at $\mathrm{pH} 7.5$ and $25^{\circ} \mathrm{C}$. The $\mathrm{CD}$ of two proteins difference is not due to differences in protein concentrations or buffer contaminants after protein purification. c FTIR analysis of CdDHN4-L and -S at room temperature with (1 $\mathrm{mg}$ powder)

\section{The protective function of CdDHN4-L and CdDHN4-S in} vitro

Both dehydrins and BSA were potent stabilizers for $\mathrm{LDH}$ at $50{ }^{\circ} \mathrm{C}$ with different concentration ratios of $1: 1$, 2:1 and 5:1 (test protein: LDH) (Fig. 6a). The relative activities of $\mathrm{LDH}$ incubated with CdDHN4-L or CdDHN4-S at $50{ }^{\circ} \mathrm{C}$ were higher than that with BSA at concentration ratios of 1:1 and 2:1 (test protein: LDH), especially when the ratio was $2: 1$. Similar results were obtained when LDH was placed at freeze $\left(-20{ }^{\circ} \mathrm{C}\right)$-thawing conditions (Fig. $6 \mathrm{~b}$ ). The relative activities of $\mathrm{LDH}$ were completely recovered to the normal level ( 0 cycle) in the presence of the two dehydrins at first two freeze-thawing cycles and the activities of LDH were significantly higher in the presence of CdDHN4-L and CdDHN4-S than in BSA at first two freeze-thawing cycles. The relative activities of $\mathrm{LDH}$ incubated with CdDHN4-L and $-\mathrm{S}$ and BSA at $50{ }^{\circ} \mathrm{C}$ or freeze-thawing

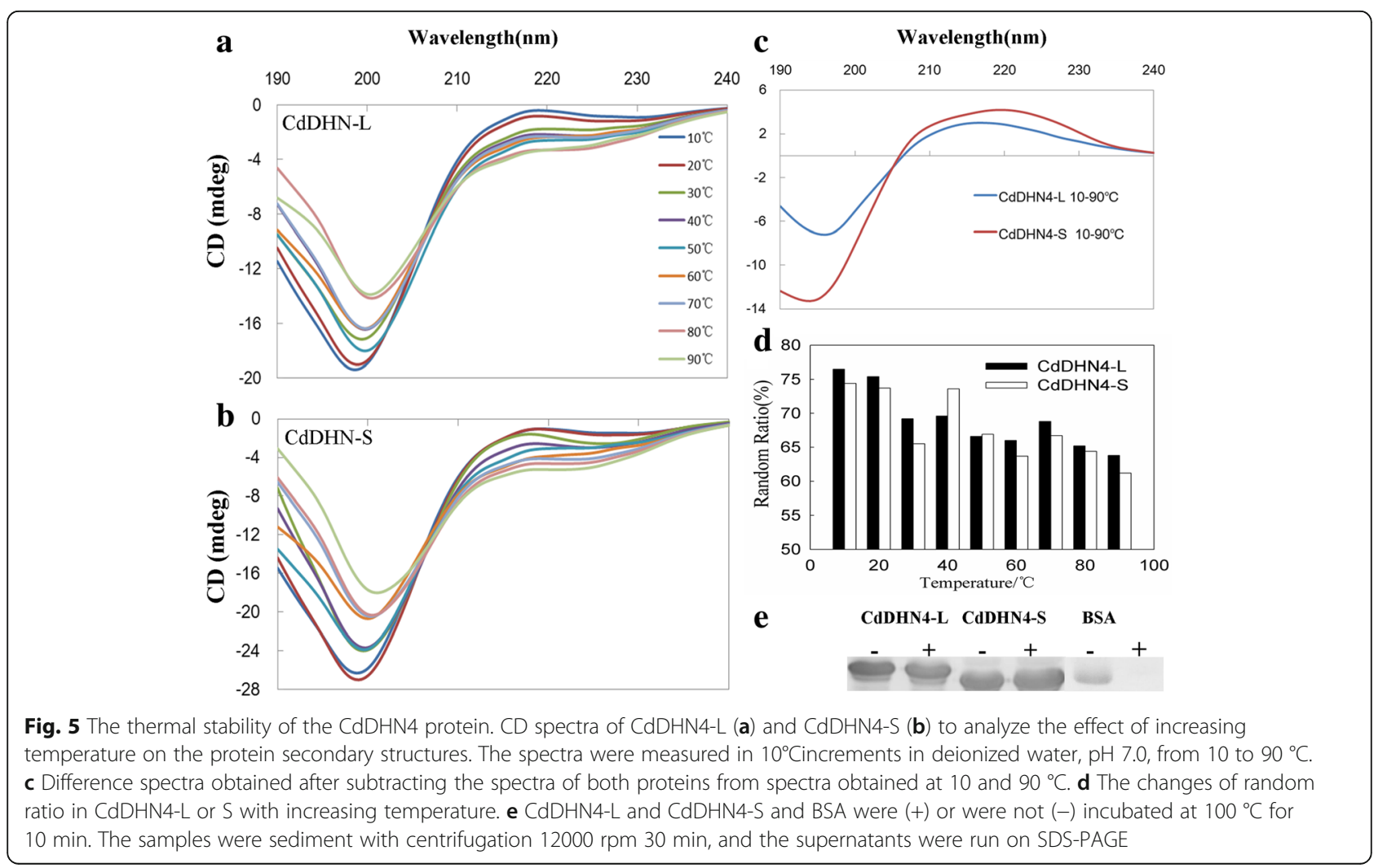



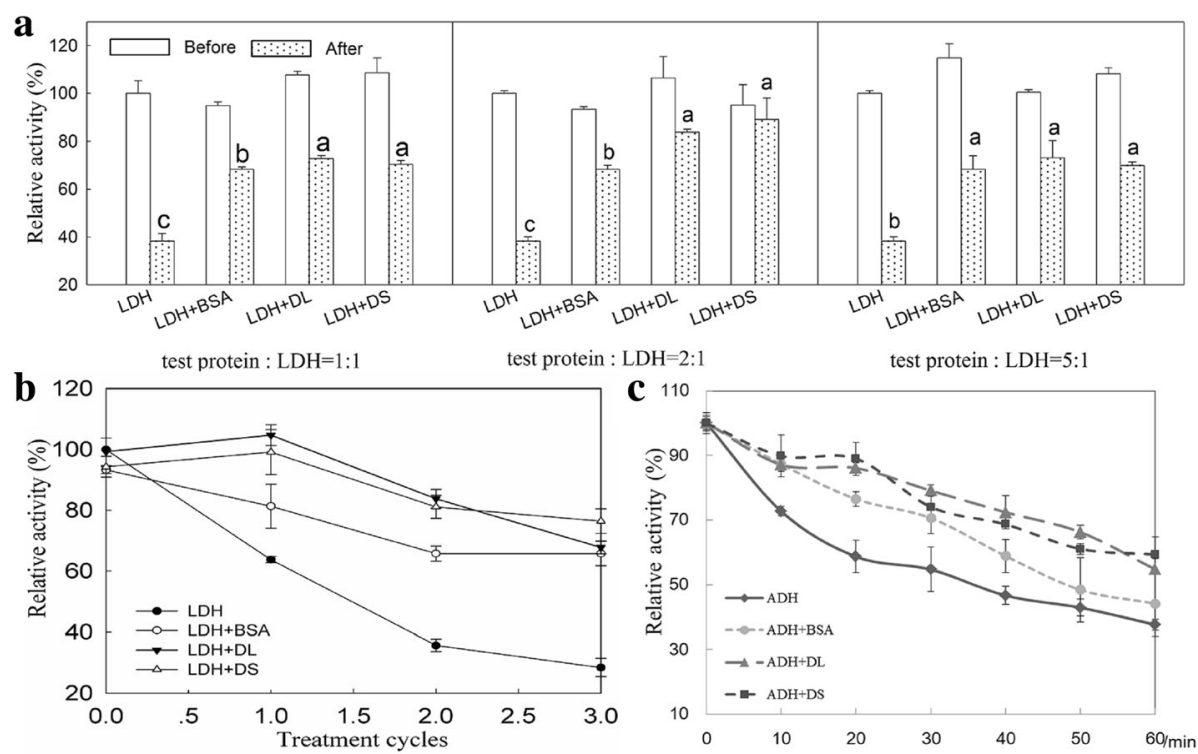

Fig. 6 Effect of CdDHN4-L and CdDHN4-S on lactate dehydrogenase (LDH) activity and alcohol dehydrogenase (ADH). a CdDHN4-L and CdDHN4-S at different concentrations was added to LDH. Relative enzyme activities are shown as percentage. Before-Activities of non-treated enzymes, After- the reaction solution was incubated $10 \mathrm{~min}$ at $50{ }^{\circ} \mathrm{C}$. Values and bars represent means $\pm \mathrm{SD}$ (three individual experiments). Different letters show significant differences $(\mathrm{p}<0.05)$ as determined by ANOVA analysis among addition with BSA, CdDHN4-L and CdDHN4-S. b Cryoprotective activity was assayed with a ratio of 2:1 (test protein: LDH). LDH alone or in present of CdDHN4-L, CdDHN4-S or BSA protein were frozen in $-20{ }^{\circ} \mathrm{C}$ and then thawed at room temperature. $\mathbf{c}$ The heat-induced inactivation of ADH was carried out at $45^{\circ} \mathrm{C}$ for $1 \mathrm{~h}$, and enzyme activity was determined every $10 \mathrm{~min}$. Activities of non-treated enzymes are standardized (100\%)

cycles were significantly higher than that of LDH alone (Fig. 6a and b).

Both dehydrins greatly prevented the loss of ethanol dehydrogenase $(\mathrm{ADH})$ activities during $60 \mathrm{~min}$ heating treatments (Fig. 6c). The relative activities of ADH were significantly higher in the presence of CdDHN4-L and CdDHN4-S than in water controls during 60 min heating treatments, and also were significantly higher than that in the presence of BSA during most of heating time.

\section{Protein-protein interaction}

The interactions between two dehydrins and $\mathrm{ADH}$ were studied using the two methods of the protein binding and $\mathrm{BiFC}$ assay. The analyses of $\mathrm{ADH}$ protein binding with CdDHN4-L and CdDHN4-S using ProteinIso ${ }^{\circ}$ Ni-NTA Resin columns showed that ADH alone was fully eluted by $100 \mathrm{mM}$ imidazole (Fig. 7c), while most of ADH was eluted by 250 and $400 \mathrm{mM}$ imidazole in the presence of CdDHN4-L or CdDHN4-S (Fig. 7a and b). The ADH was not eluted by $10 \mathrm{mM}$ imidazole in the presence of CdDHN4-S, and only a small amount of $\mathrm{ADH}$ was eluted by $10 \mathrm{mM}$ imidazole in the presence of CdDHN4-L, but a large amount of ADH was eluted by $10 \mathrm{mM}$ imidazole without CdDHN4-L or CdDHN4-S (Fig. 7c). In addition, YFP fluorescence were detected in tobacco leaves co-transformed the recombinant vectors CdDHN4-L-cYFP and nYFP-AtADH, and vectors CdDHN4-S-cYFP and nYFP-AtADH, but were not detected in the negative control and in vectors CdDHN4-L-cYFP and nYFP-CdDHN4-S (Fig. 8).

The $\mathrm{CD}$ analysis showed that large negative peaks near $200 \mathrm{~nm}$ were observed after addition of ADH to CdDHN4-L or CdDHN4-S, although the degree of the negative peak of CdDHN4-L was mitigated by the ADH addition, CdDHN4-L and CdDHN4-S still kept the intrinsic disorder protein character in the presence of ADH (Fig. 7d), but the positive peak of CdDHN4-S near $220 \mathrm{~nm}$ was lost after addition of ADH (Fig. 7d). In the presence of $\mathrm{ADH}$, the beta conformation proportion of CdDHN4-L and CdDHN4-S increased from 23.1 to 33\% and from 27.3 to $45.8 \%$, respectively, while the random coil proportion decreased from 64.6 to $55 \%$, and from 61.4 to $51 \%$, respectively.

\section{The protein-protein interaction via electrostatic interaction}

The isoelectric point (pI) of AtADH protein (Arabidopsis thaliana, AT1G77120) was 6.19, while the pIs of CdDHN4-L and CdDHN4-S were 8.87 and 8.81, respectively. The difference of pIs between CdDHN4-L or CdDHN4-S and AtADH, and between CdDHN4-L and CdDHN4-S might be related to their protein interactions mentioned in above paragraph. To confirm this prediction, the interactive relationships between CdDHN4-L or CdDHN4-S and other three proteins with different 


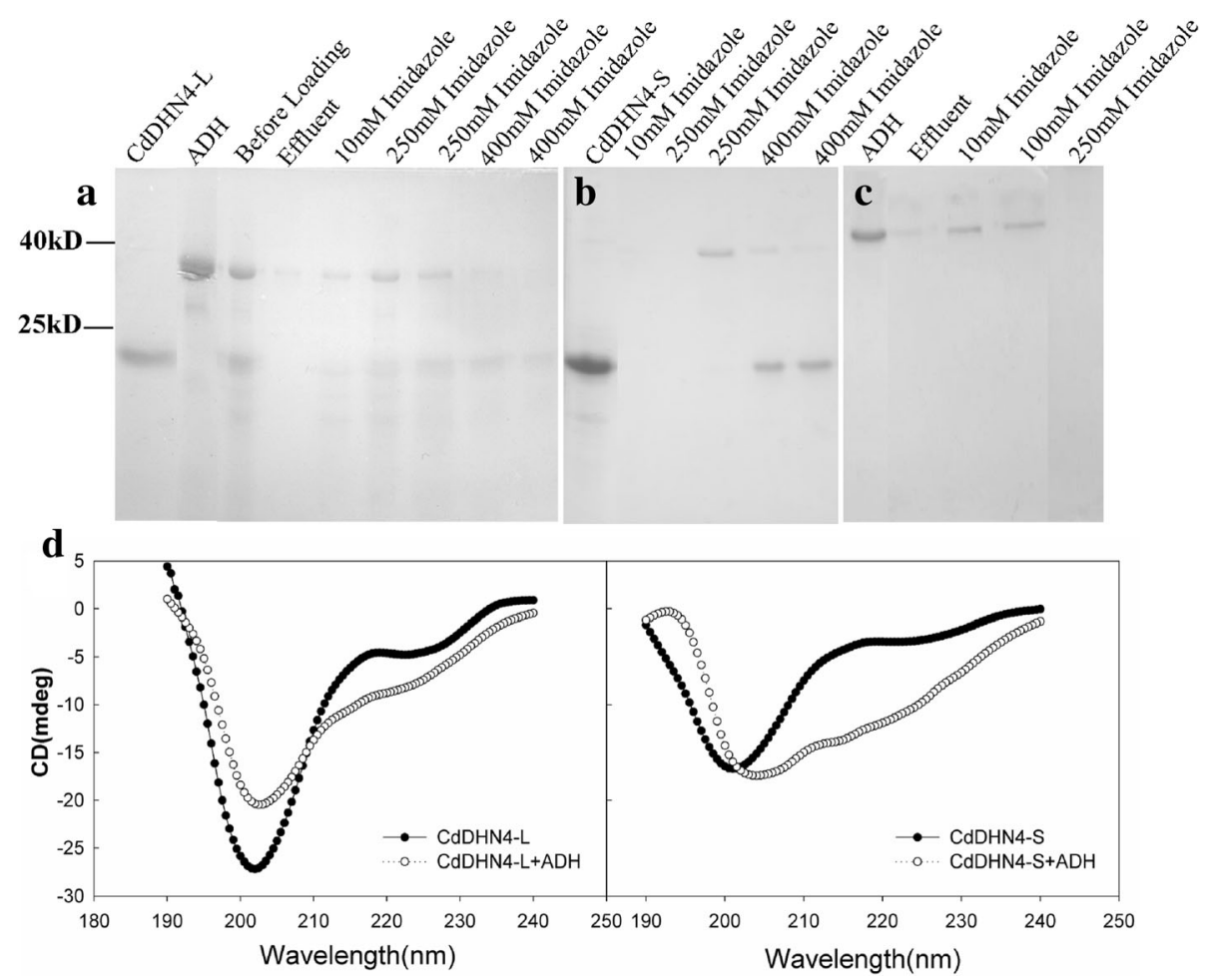

Fig. 7 The interaction between ADH and CdDHN4-L, CdDHN4-S in vitro. CdDHN4-L (a), CdDHN4-S (b) with ADH or ADH alone (c) passed through the Proteinlso ${ }^{\oplus}$ Ni-NTA Resin column. Different concentrations of imidazole eluted columns. The effluent was analyzed with SDS-PAGE. d CdDHN4-L (left) and CdDHN4-S (right) $\left(0.25 \mathrm{mg} \mathrm{mL}^{-1}\right)$ were analyzed by CD in the presence of ADH $\left(0.125 \mathrm{mg} \mathrm{mL}^{-1}\right)$ at room temperature

pIs were analyzed by BiFC assay. The results were shown in Fig. 8. The YFP fluorescence were detected in the vectors CdDHN4-L/S-cYFP and nYFP-Ms7576 with pI $8.78 / 8.81$ and 4.92 , respectively, and in the vectors CdDHN4-L/S-cYFP and nYFP-Ms0037 with pI 8.78/8.81 and 5.56, but no YFP fluorescence was detected in the vectors CdDHN4-L/S-cYFP and nYFP-Ms7916 with pI $8.78 / 8.81$ and 8.78 , and in other vectors. The YFP fluorescence intensities decreased with the reduction of pI difference between the two interactive proteins.

\section{Discussion}

In the present study, overexpression of $C d D H N 4-L$ and CdDHN4-S cloned from bermudagrass enhanced tolerance against drought and salt stresses in transgenic Arabidopsis and tolerance against salinity, low or high temperature stresses in transgenic E.coli cells, suggesting that these two dehydrins play positive roles in stress defense, similar to reported by others in plants and bacteria [26-28]. The novelty of this study is reflected by the differential effects of CdDHN4-L and CdDHN4-S. The growth rate of Arabidopsis and E.coli cells overexpressing CdDHN4-L exposed to $\mathrm{NaCl}$ at $100 \mathrm{mM}$ (Arabidopsis) and $\mathrm{NaCl}$ at $300-400 \mathrm{mM}$ and temperature at $-20{ }^{\circ} \mathrm{C}$ and $50{ }^{\circ} \mathrm{C}($ E.coli cells $)$ were higher than that overexpressing CdDHN4-S. The stability of the two dehydrin proteins under abiotic stressed conditions may affect their function on tolerance of plants against stresses. In our study, the disorder structure proportion of CdDHN4-L were higher than that of CdDHN4-S from 10 to $30{ }^{\circ} \mathrm{C}$ and from 60 to $90{ }^{\circ} \mathrm{C}$, but proportion of CdDHN4-S was higher at $40{ }^{\circ} \mathrm{C}$ in comparison with CdDHN4-L. These results indicated that CdDHN4-L was more stable than CdDHN4-S under moderate and severe stress conditions.

The K, Y and S-segments are major domains of dehydrin proteins, which determine the function of dehydrin protein. In addition, most of dehydrins have another domain, $\phi$-segments [19]. The $\phi$-segments are seldom studied and no direct evidence showed its function in dehydrin proteins because of its less conserved trait [12, 29]. Recently, Rosales et al. [22] first compared two spliced dehydrin variants, the spliced DHN1a_s and the unspliced DHN1a_u which lacked $\phi$ - and K-segments, and found that DHN1a_s had a potent cryoprotective effects on LDH activity and malate dehydrogenase activity against dehydration and partially inhibited B.cinerea growth, and concluded that $\phi$ - and K-segments played role in DHNs function in plant response to abiotic stress. However, until then there is no direct evidence showing the function of $\phi$-segments. In the present study, CdDHN4-S with the 


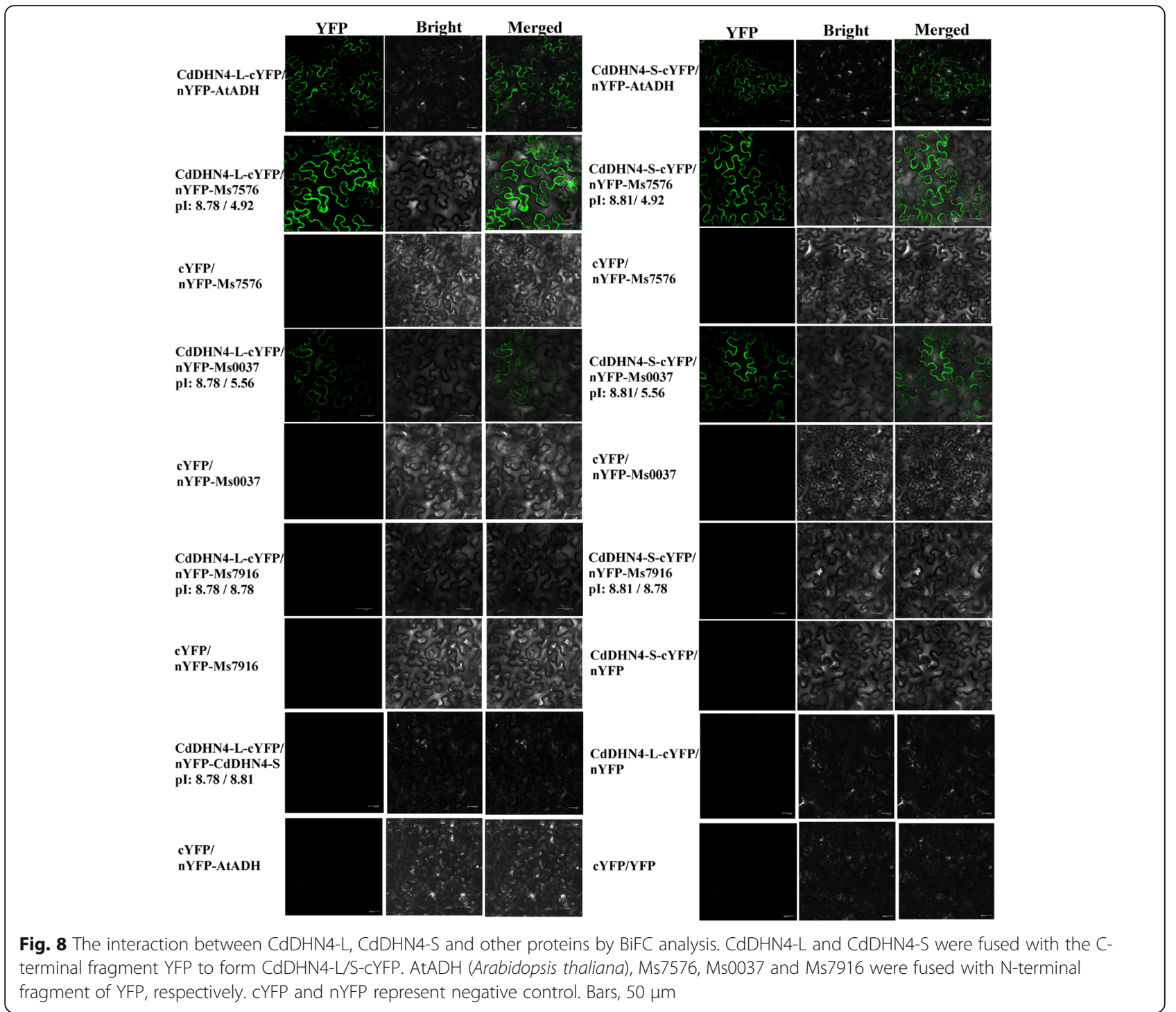

$\phi$-segment deletion exhibited differential effects from CdDHN4-L containing the $\phi$-segment, which first provided the evidence of the positive roles of $\phi$-segment in protecting plants against abiotic stress.

Dehydrins are intrinsic disorder proteins with flexible secondary structure [30]. In the present study, the CdDHN4-L and CdDHN4-S expressed typical dehydrin characteristics in the following aspects: 1) a low mobility, as seen from SDS-PAGE and western blot analysis $[10,22]$. The low mobility maybe attributed to their phosphorylation sites and high hydrophilcity [31];2) the higher sensitivity to proteases $\mathrm{K}$ and trypsin than BSA, which are attributed to their polypeptide chain that determines dehydrins to be more accessible to proteases than that of globular proteins [32]; 3) the random coil proportion of two dehydrins accounted for over $60 \%$ of total secondary structure under temperatures from 10 to $90{ }^{\circ} \mathrm{C}$ by CD analysis, and over $62.3 \%$ of unstructured ratio by FTIR analysis. The CdDHN4-L had higher random coil proportion than CdDHN4-S in both two analyses. These results demonstrated that CdDHN4-L and CdDHN4-S, especially CdDHN4-L, had highly flexible unfolded structure and thermal stability, exhibiting the properties as IDPs.

Disordered dehydrins have been shown to reduce radical reactive oxygen species from transition metal [2], and protect enzymes from free-thaw damage or heat denaturation $[29,32]$. In this study, the recovery activities of LDH and ADH in presence of CdDHN4-L and CdDHN4-S were greatly higher than that of LDH and $\mathrm{ADH}$ alone under free-thaw damage and heat stresses, indicating that the two dehydrins have strong ability of protecting enzymes, which can be attributed to their flexible unfolded structures under abiotic stress conditions $[33,34]$. Several studies have shown that dehydrins are able to bind to membranes $[3,35]$, water [36] and metal ions [37, 38]. In this study, 
CdDHN4-L and CdDHN4-S prevented ADH elution under lower concentration of imidazole, but the ADH alone was easily eluted under lower concentration of imidazole, indicating that CdDHN4-L and CdDHN4-S were able to bind to ADH protein. The YFP fluorescence observed in vectors of CdDHN4-L/S-cYFP and nYFP-AtADH further confirmed the direct interaction between dehydrins and ADH.

Many evidences show that IDPs always share properties of a flexible conformation, a high proportion of disorder-promoting residues, and a lack of stable structure or only some residual secondary structure when dehydrins scatter in solution or bind with other proteins, metal ions or lipid vesicles [39]. For example, trifluoroacetic acid and slow drying usually induce dehydrins to increase their $\alpha$-helix [40, 41], while dehydrins binding to lipid vesicles always accompany with an increase in $\beta$-sheet $[42,43]$. The disorder degrees of CdDHN4-L and CdDHN4-S binding to ADH were lower than that of dehydrin itself, and these conformation changes maybe attribute to the interaction between CdDHN4 and $\mathrm{ADH}$ [2]. In addition, $\beta$-sheet contents in CdDHN4-L and CdDHN4-S were increased in the presence of ADH. The binding plasticity and self-conformation change allow dehydrins to interact with multiple partners, which are critical for their function [15]. Comparing with CdDHN4-L, CdDHN4-S had different refolding structure in which the positive peak near $220 \mathrm{~nm}$ disappeared with addition of $\mathrm{ADH}$, which may be attributed to the $\phi$-segment deletion. Furthermore, the lower flexible unfolded structure and thermal stability in CdDHN4-S may also be attributed to its $\phi$-segment deletion compared with CdDHN4-L. A further study should be conducted to investigate the effect of $\phi$-segment deletion on the structure and function of CdDHN4-L.

The typical cytoplasmic proteins always have a negatively charged surface at physiological $\mathrm{pH}$ [44], and the numerous natively unfolded proteins change their conformations after incubation with other molecules such as proteins and ions or chemicals due to their negative charged surface [14]. The dehydrins are unfolded proteins, which have been reported to protective plants exposed to abiotic stresses by molecular chaperone [45]. In the present study, there were strong binding activities between CdDHN4-L or CdDHN4-S with ADH, which increased the activities of $\mathrm{ADH}$ and $\mathrm{LDH}$ under free-thaw and heat stress. Meanwhile the secondary structure of CdDHN4-L and CdDHN4-S were still kept well under different temperature conditions and in the presence of ADH although the secondary structures had slightly changed, indicating that the two dehydrins played a molecular chaperone function to $\mathrm{ADH}[5,46]$.

The classical chaperone acts to prevent aggregation of unfolded polypeptides and assists in the correct refolding of chaperone-bound denatured polypeptides through electrostatic forces, For example, Eriksson et al. [3] reported that Lti30 (dehydrin) interacted electrostatically with vesicles of both zwitterionic (phosphatidyl choline) and negatively charged phospholipids (phosphatidyl glycerol, phosphatidyl serine, and phosphatidic acid) with a stronger binding to membranes with high negative surface potential. At the present, the molecular chaperone via electrostatic forces is speculated by $\mathrm{pI}$ of chaperone and client proteins, and no direct evidence is reported. In the present study, The YFP fluorescence, reflecting binding activities between $\mathrm{CdDHN} 4-\mathrm{L} / \mathrm{S}$ and other client proteins via $\mathrm{BiFC}$ assay, were detected in the vectors of CdDHN4-L/S-cYFP and nYFP-Ms7576, or nYFP-Ms0037, or nYFP-AtADH, respectively, but no YFP fluorescence were detected in the vectors of CdDHN4-L/ S-cYFP and nYFP-Ms7916, as well as CdDHN4-L-cYFP and nYFP-CdDHN4-S. The YFP fluorescence intensities decreased with the reduction of $\mathrm{pI}$ difference between the two binding proteins, indicating that the two dehydin proteins were bounded with the first three tested proteins (Ms7576, Ms0037 and AtADH) via electrostatic forces, and the binding ability was positive to the $\mathrm{pI}$ difference between the two binding proteins. These results first provided the evidence of molecular chaperone function of dehydrins via electrostatic forces.

\section{Conclusions}

This study demonstrated that CdDHN4-L and CdDHN4-S cloned from bermudagrass were unfolded proteins and overexpression of the two dehydrins enhanced tolerance to drought and salt stress in transgenic Arabidopsis, and to salt, extreme temperatures stress in transgenic E.coli cells. The tolerance against stresses of CdDHN4-L with the $\phi$-segment was greater than CdDHN4-S lacking of the $\phi$-segment, which was corresponded with the more stability of the unfolded structure proteins under unfavorable temperature. The $\phi$-segment could account for the differential effects between CdDHN4-S and CdDHN4-L. The strong binding activities occurred between CdDHN4-L or CdDHN4-S with Ms7576, Ms0037 and AtADH via close-range electrostatic forces, and the binding abilities were positive to their pI difference between the two binding proteins. The protective roles of CdDHN4-L and CdDHN4-S on plants against abiotic stresses could be due to the direct protein-protein interaction driving by electrostatic forces. In future studies, we will further evaluate the difference between CdDHN4-L and CdDHN4-S on their structure and function under abiotic stressed conditions by homologous transforming the two dehydrin genes into bermudagrass, and further understand the function of $\phi$-segment in dehydrins for protecting plants against abiotic stress,as well as its influence on protein-protein interaction. 


\section{Methods}

\section{Abiotic stress in Arabidopsis}

Two dehydrins, CdDHN4-L and CdDHN4-S have been obtained from bermudagrass (Cynodondactylon L.) 'Tifway'. The sequence of $C d D H N 4$ without the terminating codon was amplified and inserted into the BamHI/SpeI sites of PHB-CFP to generate the construct PHB-CdDHN4-CFP. After sequencing, the constructs were introduced into Agrobacterium tumefaciens strain GV3101, and transformed into Arabidopsis (Ecotype Col-0, from Lian's Lab) by the floral dip method [47]. Seeds of $\mathrm{T}_{3}$ transgenic Arabidopsis plants overexpressing CdDHN4-L or CdDHN4-S (Fig. 2b) and the wild type (Columbia) were placed on petri dishes with MS medium and seedlings were grown for two weeks in the petri dishes. For drought stress, the seeds were grown in the MS medium with 0 or $100 \mathrm{mM}$ Sorbitol. Primary root length, fresh weight of whole plant in leaves were measured after 10 days. For salt stress, the transgenic and wild type plants were grown in the MS medium supplemented with $0,50,75$ and $100 \mathrm{mM} \mathrm{NaCl}$ for 7 days. Seed germination rate, primary root length and fresh weight were measured to evaluate effects of salinity stress. All of the experiments were repeated three times.

Total RNA were isolated from plant leaves using the TransZol Up Plus RNA Kit. First-strand cDNA was synthesized using TransScript One-Step gDNA Removal and cDNA Synthesis SuperMix (TransGen Biotech).The semi-quantitative RT-PCR were conducted as follows: $95{ }^{\circ} \mathrm{C}$ for $5 \mathrm{~min}$, then 26 cycles of $95{ }^{\circ} \mathrm{C}$ for $30 \mathrm{~s}, 58{ }^{\circ} \mathrm{C}$ for $30 \mathrm{~s}$, and $72{ }^{\circ} \mathrm{C}$ for $20 \mathrm{~s}$ for both CdDHN4 and actin.

\section{Protein extraction and purification}

A recombinant expression of CdDHN4-L and CdDHN4-S proteins (Additional file 3) in prokaryote was performed according to a method previous reported by Hara et al. [2]. In brief, the open reading frames of CdDHN4-L and CdDHN4-S were expressed by the pET-21a E.coli expression system (Novagen, WI, USA). These recombinant proteins have His-tag sequences at the C-terminus. The E.coli strain Rosetta (DE3) was used as the host. The bacterial stain was pre-cultured at $37{ }^{\circ} \mathrm{C}$, and $1 \mathrm{mM}$ (IPTG) isopropyl- $\beta$-dthiogalactopyranoside was added to the culture. After incubation for $6 \mathrm{~h}$ at $30-^{\circ} \mathrm{C}$, bacterial cells (300 mL of culture) were centrifuged at $12000 \mathrm{~g}$ for $20 \mathrm{~min}$. Bacterial thallus were lysed by sonication in $1 / 10$ PBS (pH 7.4) and $1 \mathrm{mM}$ phenylmethylsulfonyl fluoride. The lysate was centrifuged at $12000 \mathrm{~g}$ for $30 \mathrm{~min}$ at $4{ }^{\circ} \mathrm{C}$. The CdDHN4-L and CdDHN4-S proteins were purified subsequently by a ProteinIso ${ }^{\circ}$ Ni-NTA Resin $(5 \mathrm{~mL}$, TRANSGEN BIOTECH, Beijing, China) immobilizing $\mathrm{Ni}^{2}$ ${ }^{+}$and then were eluted by different concentrations of imidazole. Samples were desalted using an ultrafiltration tube (Millipore Amicon ${ }^{\bullet}$ Ultra). The CdDHN4-L and CdDHN4-S was stored as a water solution (1-2 $\mathrm{mg} \mathrm{mL}^{-}$

$\left.{ }^{1}\right)$ at $-80{ }^{\circ} \mathrm{C}$ until used, respectively. The recombinant proteins were identified by the sodium dodecyl sulfate-polyacrylamide gel electrophoresis (SDS-PAGE) gel stained with Coomassie Brilliant Blue and western blot with Anti-dehydrin (AS07206, Agrisera, Sweden).

\section{Circular dichroism spectroscopy}

Proteins CdDHN4-L and CdDHN4-S were analyzed with a Circular dichroism (CD) spectropolarimeter (J-815, JASCO, Japan). Protein samples $\left(0.25 \mathrm{mg} \mathrm{mL}^{-1}\right)$ were combined in water solution $(\mathrm{pH} 7.0)$ with a $0.1 \mathrm{~cm}$ optical path length cell at room temperature. The scan was performed from $190 \mathrm{~nm}$ to $250 \mathrm{~nm}$. The scan speed, cell length, and band width were $50 \mathrm{~nm} \mathrm{~min}{ }^{-1}, 1 \mathrm{~mm}$, and $2 \mathrm{~nm}$, respectively. Then the secondary structures of both proteins at various temperatures were analyzed at a range of temperatures from 10 to $90{ }^{\circ} \mathrm{C}$.

CdDHN4-L and CdDHN4-S $\left(0.25 \mathrm{mg} \mathrm{mL}^{-1}\right)$ were also subjected to $\mathrm{CD}$ spectropolarimeter in the presence of alcohol dehydrogenase $\left(0.125 \mathrm{mg} \mathrm{mL}^{-1}\right)$ at room temperature.

\section{Fourier transform infrared spectroscopy (FTIR) analysis} FTIR spectroscopy was performed as described by shih et al. [14] with slight modification. Purified recombinant CdDHN4-L and $-\mathrm{S}$ proteins were dried in Cryogenic dryer to be solid. The dried protein samples $(1 \mathrm{mg})$ were poured on circular plates (ATR). FTIR spectra in the range between 4000 and $525 \mathrm{~cm}^{-1}$ were recorded at room temperature, with a spectral resolution of $4 \mathrm{~cm}^{-1}$, on an IR/Nicolet 6700 spectrometer (USA).

The secondary structure of two proteins were analyzed at the spectral region between 1700 and $1500 \mathrm{~cm}^{-1}$ according to shih et al. [14]. Secondary structure components were derived from the second derivative spectra of the amide-I bands according to Gaussin FTIR (Software, PeakFit).

\section{Intrinsic disorder protein analysis}

The resistance to heat induced aggregation was analyzed with SDS-PAGE. CdDHN4-L and CdDHN4-S $\left(0.25 \mathrm{mg} \mathrm{mL}^{-1}\right)$ of and BSA (as a control, its isoelectric point is 8.6) were treated at $100{ }^{\circ} \mathrm{C}$ for $10 \mathrm{~min}$ and centrifuged at $12,000 \mathrm{~g}$ for $20 \mathrm{~min}$ at room temperature. The supernatants were analyzed with a $12.5 \%$ SDS-PAGE gel.

Protease sensitivity of CdDHN4-L and CdDHN4-S were tested with two proteases: proteinase K (broad specificity) and trypsin (narrow specificity). Protein samples $\left(0.5 \mathrm{mg} \mathrm{mL}^{-1}\right)$ were treated with different ratios of protease for $30 \mathrm{~s}$. The reactions were stopped by adding $2^{*}$ loading buffer and heated at $100{ }^{\circ} \mathrm{C}$ for $5 \mathrm{~min}$. Then samples were identified by SDS-PAGE. 


\section{Thermal and freeze-thawing inactivation of lactate dehydrogenase}

Lactate dehydrogenase (LDH, from rabbit muscle, Sigma, USA) activity was determined in triplicates using aliquots of $5 \mu \mathrm{L}$ in $200 \mu \mathrm{L}$ of $100 \mathrm{~mm} \mathrm{NaH} \mathrm{PO}_{4}$ buffer (pH 6.0), $2 \mathrm{~mm}$ pyruvate, $100 \mathrm{~mm} \mathrm{NADH}$. The decrease in $\mathrm{A}_{340}$ was monitored in 96-well microplate with a Microplate reader (Synergy| ${ }^{2}$, BioTek, USA). Enzymatic activity was followed at room temperature by recording the decrease in $340 \mathrm{~nm}$ for $5-6 \mathrm{~min}$. Heat inactivation of $\mathrm{LDH}$ was assayed. A mixture of $60 \mu \mathrm{L}$ containing $10 \mu \mathrm{g} \mathrm{mL} \mathrm{m}^{-1} \mathrm{LDH}$ and the indicated amounts CdDHN4-L, CdDHN4-S or BSA protein were incubated $10 \mathrm{~min}$ at $50{ }^{\circ} \mathrm{C}$. Samples measuring $20 \mu \mathrm{L}$ were assayed for LDH activity in a final volume of $200 \mu \mathrm{L}$. Cryoprotective activity was assayed with a mixture of $60 \mu \mathrm{L}$ containing $10 \mu \mathrm{g} \mathrm{mL}{ }^{-1} \mathrm{LDH}$ and the same amounts of CdDHN4-L, CdDHN4-S or BSA protein were frozen at $-20{ }^{\circ} \mathrm{C}$ and then thawed at room temperatures. Enzyme activities were determined every $10 \mathrm{~min}$ until 3 freeze-thawing.

\section{Thermal inactivation of alcohol dehydrogenase}

The heat-induced inactivation of yeast alcohol dehydrogenase $(\mathrm{ADH})$ was carried out at $45{ }^{\circ} \mathrm{C}$ for $1 \mathrm{~h}$. ADH ( $1 \mathrm{mg} \mathrm{mL}{ }^{-1}$ ) was mixed with same concentration of CdDHN4-L, CdDHN4-S and BSA (as a control) in $100 \mathrm{mM} \mathrm{NaH}_{2} \mathrm{PO}_{4}$ and $0-250 \mathrm{mM} \mathrm{NaCl}, \mathrm{pH}$ 8.8). The samples were incubated on ice for $5 \mathrm{~min}$ before assay. Then, the reaction solution was placed into a $45{ }^{\circ} \mathrm{C}$ water bath, and enzyme activity was determined every $10 \mathrm{~min}$. The enzyme activity was measured with $1.25 \mathrm{mM}$ ethanol and $2 \mathrm{mM} \mathrm{NAD}^{+}\left(100 \mathrm{mM} \mathrm{NaH}_{2} \mathrm{PO}_{4}\right.$, $\mathrm{pH} 7.5$ ) by adding $20 \mu \mathrm{L}$ (to $200 \mu \mathrm{L}$ ) of reaction solution. The increase in $\mathrm{NADH} \mathrm{A}_{340}$ was followed at room temperature with microplate reader.

\section{Protein-binding assay}

The interaction between protein (such as $\mathrm{ADH}$ ) and CdDHN4-L or CdDHN4-S was analyzed by a ProteinIso ${ }^{\circ}$ Ni-NTA Resin in vitro. ADH samples were prepared in the presence and absence of purified CdDHN4-L or CdDHN4-S and passed through the ProteinIso ${ }^{\circ}$ Ni-NTA Resin column. Then, different concentrations of imidazole eluted columns. The amount of the protein in the flow through is characteristic of the strength of the interaction. The effluent was analyzed with $12.5 \%$ SDS-PAGE.

For Bimolecular fluorescence complementation (BiFC) analysis, the vectors pXY106-nYFP and pXY104-cYFP supplied by Yang Hongquan's lab were used. Then the full-length open reading frame of CdDHN4-L, CdDHN4-S and AtADH gene (Arabidopsis thaliana, Gene ID in NCBI: 844047) were cloned into the expression vectors, respectively. Subsequently, CdDHN4-L-cYFP, CdDHN4-S-cYFP,
ADH-nYFP and CdDHN4-S-nYFP were transformed into GV3101 and transiently co-transformed into 5-weeks old tobacco leaves (N.benthamiana). Yellow fluorescent protein (YFP) signals were detected by confocal microscopy (Leica Microsystems, Wetzlar, Germany) after 48-72 h in darkness conditions.

Multiple proteins used in BiFC analysis were obtained and kept in our lab (data not shown here). The isoelectric point (pI) of the protein Ms7576, Ms0037 and Ms7916 were 4.92, 5.56 or 8.78, respectively. These protein molecular weights were $27.3,24.8$ or $20.8 \mathrm{kDa}$, respectively. All molecular weight and pI of the proteins were predicted by DNAMAN software, based on amino acid sequences. All primers used in this study showed in Additional file 4.

\section{Data analysis}

The data of root length, and spectral absorbance were subjected to the analysis of variance and treatment means were separated using the least significance test (LSD) at a probability of 0.05 . The characteristics of protein primary sequences, including $\mathrm{pI}$ values, net charges and molecular weight were analyzed by ExPASy (http:// web.expasy.org/protparam).

\section{Additional files}

Additional file 1: BSA, CdDHN4-L and CdDHN4-S were treated with Trypsin and proteinase K. (DOCX $152 \mathrm{~kb}$ )

Additional file 2: Band positions and individual contributions by various secondary structures of $\mathrm{CdDHN4-L}$ and $\mathrm{CdDHN4-S}$ proteins determined by curve fitting of the composite amide-l band of FTIR spectra. (DOCX $15 \mathrm{~kb}$ )

Additional file 3: Analysis of protein extracts from IPTG induced E.coli Rosetta (DE3) expressing the recombinant CdDHN4-L and CdDHN4-S. (DOCX 514 kb)

Additional file 4: Primer sets used in this study. (DOCX $17 \mathrm{~kb}$ )

\section{Abbreviations}

ADH: Alcohol dehydrogenase; At: Arabidopsis thaliana; BiFC: Bimolecular fluorescence complementation; BSA: Albumin from bovine serum; CD: Circular dichroism; DHN: Dehydrin; FTIR: Fourier transform infrared spectroscopy; IDPs: Intrinsically disordered proteins; IPTG: Isopropyl $\beta-D-$ Thiogalactoside; LDH: Lactic dehydrogenase; LEA: Late embryogenesis abundant; LSD: Least significance test; MS: Murashige and Skoog medium; PAGE: Polyacrylamide gel electrophoresis; pl: Isoelectric point; Sorb: Sorbitol; WT: Wild type; YFP: Yellow fluorescence protein

\section{Acknowledgements}

We would like to thank Dr. Hongli Lian (Shanghai Jiao Tong University) for providing us with the BiFC vector, and Dr. Ruibin Wang, Xiangzhong Cai (Shanghai Jiao Tong University) for the CD/FTIR analysis and confocal laser canning microscopy.

\section{Funding}

This work was supported by the Chinese Natural Science Foundation General Projects (Nos. 31872419 and 31572451), National Key R\&D Program of China (No. 2017FY100600) and the Scientific Research Project of Shanghai Municipal Administration of Landscaping and City Appearance (G162411). The funding bodies of the research are Chinese Natural Science Foundation General Projects, and they providing funds play very important roles in experiment test and data collection. The data analysis of study and publish 
fee are supported National Key R\&D Program of China and the Scientific Research Project of Shanghai Municipal Administration of Landscaping and City Appearance.

\section{Availability of data and materials}

The datasets used and/or analysed during the current study are available from the corresponding author on reasonable request.

\section{Authors' contributions}

YA, PZ and AML designed and performed all experiments, including data analyses wrote and revised the manuscript. LTS, XCL and QX performed some experiments. BRH wrote some section and revised the manuscript. All authors have approved the manuscript for publication.

\section{Ethics approval and consent to participate}

The source of the 'Tifway' (bermudgrass) used in our study come from our lab (Grass science lab, Shanghai Jiao Tong University). Seeds of Arabidopsis (Ecotype Col-0) were provided by Hongli Lian's Lab (Shanghai Jiao Tong University). All plants materials are allowed to be used and provided in this study and it's not endangered materials or species.

\section{Consent for publication}

Not applicable.

\section{Competing interests}

The authors declare that they have no competing interest.

\section{Publisher's Note}

Springer Nature remains neutral with regard to jurisdictional claims in published maps and institutional affiliations.

\section{Author details \\ ${ }^{1}$ School of Agriculture and Biology, Shanghai Jiao Tong University, Shanghai 200240, People's Republic of China. ${ }^{2}$ Key Laboratory of Urban Agriculture, Ministry of Agriculture, Shanghai 201101, People's Republic of China. 3Shanghai Chenshan Botanical Garden, Shanghai 201602, People's Republic of China. ${ }^{4}$ Department of Plant Biology and Pathology, Rutgers, the State University of New Jersey, New Jersey, NJ 08901, USA.}

\section{Received: 15 March 2018 Accepted: 29 October 2018}

\section{Published online: 26 November 2018}

\section{References}

1. Allagulova CR, Gimalov FR, Shakirova FM, Vakhitov VA. The plant dehydrins: structure and putative functions. Biochemistry-Moscow. 2003:68:945-51.

2. Hara M, Kondo M, Kato T. A KS-type dehydrin and its related domains reduce $\mathrm{Cu}$-promoted radical generation and the histidine residues contribute to the radical-reducing activities. J Exp Bot. 2013;64:1615-24.

3. Eriksson SK, Kutzer M, Procek J, Gröbner G, Harryson P. Tunable membrane binding of the intrinsically disordered Dehydrin Lti30, a cold-induced plant stress protein. Plant Cell. 2011;23:2391-404.

4. Chatelain E, Hundertmark M, Leprince O, Gall SL, Satour P, Stéphanie DP, et al. Temporal profiling of the heat-stable proteome during late maturation of Medicago truncatula seeds identifies a restricted subset of late embryogenesis abundant proteins associated with longevity. Plant Cell Environ. 2012:35:1440-55.

5. Hughes SL, Schart V, Malcolmson J, Hogarth KA, Martynowicz DM, TralmanBaker $\mathrm{E}$, et al. The importance of size and disorder in the Cryoprotective effects of Dehydrins. Plant Physiol. 2013;163:1376-86.

6. Koag MC. The binding of maize DHN1 to lipid vesicles. Gain of structure and lipid specificity. Plant Physiol. 2003;131:309-16.

7. Agarwal T, Upadhyaya G, Halder T, Mukherjee A, Majumder AL, Ray S. Different dehydrins perform separate functions in Physcomitrella patens. Planta. 2016;245:101-18.

8. Hara M, Monna S, Murata T, Nakano T, Amano S, Nachbar M, et al. The Arabidopsis KS-type dehydrin recovers lactate dehydrogenase activity inhibited by copper with the contribution of his residues. Plant Sci. 2016; 245:135-42

9. Hughes S, Graether SP. Cryoprotective mechanism of a small intrinsically disordered dehydrin protein. Protein Sci. 2011;20:42-50
10. Kovacs D, Kalmar E, Torok Z, Tompa PE. Chaperone activity of ERD10 and ERD14, two disordered stress-related plant proteins. Plant Physiol. 2008;147: 381-90.

11. Shinde S, Islam MN, Ng CKY. Dehydration stress-induced oscillations in LEA protein transcripts involves abscisic acid in the moss, Physcomitrella patens. New Phytol. 2012:195:321-8.

12. Graether SP, Boddington KF. Disorder and function: a review of the dehydrin protein family. Front Plant Sci. 2014;5:576.

13. Tompa P, Fersht A. Structure and function of intrinsically disordered proteins. 1st ed. Biophysics: Chapman \& Hall/CRC Press; 2009

14. Shih MD, Hsieh TY, Lin TP, Hsing YIC, Hoekstra FA. Characterization of two soybean (Glycine max L.) LEA IV proteins by circular dichroism and Fourier transform infrared spectrometry. Plant Cell Physiol. 2010; 51:395-407

15. Sun X, Rikkerink EH, Jones WT, Uversky VN. Multifarious roles of intrinsic disorder in proteins illustrate its broad impact on plant biology. Plant Cell. 2013;25:38-55

16. Uversky VN. Intrinsically disordered proteins from a to Z. Int J BiochemCell B. 2011:43:1090-103.

17. Salleh FM, Evans K, Goodall B, Machin H, Mowla SB, Mur LA. A novel function for a redox-related LEA protein (SAG21/AtLEA5) in root development and biotic stress responses. Plant Cell Enviro. 2012;35:418-29.

18. Pazos F, Pietrosemoli N, García-Martín JA, Solano R. Protein intrinsic disorder in plants. Front Plant Sci. 2013:4:363.

19. Close TJ. Dehydrins: a commonality in the response of plants to dehydration and low temperature. Physiol. Plantarum. 1997;100:291-6.

20. Close TJ. Dehydrins: emergence of a biochemical role of a family of plant dehydration proteins. Physiol Plantarum. 1996;97:795-803.

21. Hernández-Sánchez IE, Maruri-López I, Ferrando A, Carbonell J, Graether SP, Jiménez-Bremont JF. Nuclear localization of the dehydrin OpsDHN1 is determined by histidine-rich motif. Front Plant Sci. 2015;6:702.

22. Rosales R, Romero I, Escribano MI, Merodio C, Sanchez-Ballesta MT. The crucial role of $\Phi$ - and K-segments in the in vitro functionality of Vitis vinifera dehydrin DHN1a. Phytochemistry. 2014;108:17-25.

23. Kosová K, Vítámvás P, Prášil IT. The role of dehydrins in plant response to cold. Biol Plantarum. 2007:51:601-17.

24. Vornam B, Gailing O, Derory J, Plomion C, Kremer A, Finkeldey R. Characterisation and natural variation of a dehydrin gene in Quercus petraea (Matt.) Liebl. Plant Biol. 2011;13:881-7.

25. Lv A, Fan N, Xie J, Yuan S, An Y, Zhou P. Expression of CdDHN4, a novel YSK2-type Dehydrin gene from Bermudagrass, responses to drought stress through the ABA-dependent signal pathway. Front Plant Sci. 2017:8:748

26. Xie C, Zhang R, Qu Y, Miao Z, Zhang Y, Shen X, et al. Overexpression of MtCAS31 enhances drought tolerance in transgenic Arabidopsis by reducing stomatal density. New Phytol. 2012;195:124-35.

27. Drira M, Saibi W, Amara I, Masmoudi K, Hanin M, Brini F. Wheat Dehydrin Ksegments ensure bacterial stress tolerance, Antiaggregation and antimicrobial effects. Appl Biochem Biotech. 2015:175:3310-21.

28. Liu Y, Wang L, Zhang T, Yang X, Li D. Functional characterization of KS-type dehydrin $\mathrm{ZmDHN} 13$ and its related conserved domains under oxidative stress. Sci Rep. 2017;7:7361

29. Drira M, Saibi W, Brini F, Gargouri A, Masmoudi K, Hanin M. The K-segments of the wheat Dehydrin DHN-5 are essential for the protection of lactate dehydrogenase and $\beta$-glucosidase activities in vitro. Mol Biotechnol. 2012 54:643-50.

30. Mouillon JM. Structural investigation of disordered stress proteins. Comparison of full-length Dehydrins with isolated peptides of their conserved segments. Plant Physiol. 2006;141:638-50.

31. Receveur K. Assessing protein disorder and induced folding. Proteins. 2005; 62:24-45.

32. Cuevas-Velazquez $\mathrm{CL}$, Saab-Rincón $\mathrm{G}$, Reyes $\mathrm{J}$, et al. The unstructured Nterminal region of Arabidopsis group 4 Late Embryogenesis Abundant Proteins (LEA) is required for folding and for chaperone-like activity under water deficit. J Bio Chem. 2016; 291:10893.

33. Hara M, Terashima S, Kuboi T. Characterization and cryoprotective activity of cold-responsive dehydrin from Citrus unshiu. J Plant Physiol. 2001:158:1333-9.

34. Momma M, Kaneko S, Haraguchi K, Matsukura U. Peptide mapping and assessment of Cryoprotective activity of 26/27-kDa Dehydrin from soybean seeds. Biosci Biotechnol Biochem. 2014;67:1832-5. 
35. Koag MC, Wilkens S, Fenton RD, Resnik J, Vo E, Close TJ. The K-segment of maize DHN1 mediates binding to anionic phospholipid vesicles and concomitant structural changes. Plant Physiol. 2009;150:1503-14.

36. Tompa P, Bánki P, Bokor M, Kamasa P, Kovács D, Lasanda G, et al. Proteinwater and protein-buffer interactions in the aqueous solution of an intrinsically unstructured plant dehydrin: NMR intensity and DSC aspects. Biophys J. 2006;91:2243-9.

37. Liu G, Xu H, Zhang L, Zheng Y. Fe binding properties of two soybean (Glycine max L.) LEA4 proteins associated with antioxidant activity. Plant Cell Physiol. 2011;52:994-1002.

38. Nachbar M, Mozafari M, Krull F, Maul K, Preu L, Hara M, et al. Metal ionDehydrin interactions investigated by affinity capillary electrophoresis and computer models. J Plant Physiol. 2017;216:219-28.

39. Sun J, Nie L, Sun G, Guo J, Liu Y. Cloning and characterization of dehydrin gene from Ammopiptanthus mongolicus. Mol Biol Rep. 2013:40:2281-91.

40. Boudet J, Buitink J, Hoekstra FA, Rogniaux H, Larré C, Satour P, et al. Comparative analysis of the heat stable proteome of radicles of Medicago truncatula seeds during germination identifies late embryogenesis abundant proteins associated with desiccation tolerance. Plant Physiol. 2006;140:1418-36.

41. Haaning S, Radutoiu S, Hoffmann SV. An unusual intrinsically disordered protein from the model LegumeLotus japonicusStabilizes Proteinsin vitro. J Biol Chem. 2008;283:31142.

42. Rahman LN, Chen L, Nazim S, Bamm W, Yaish MW, Moffatt BA, et al. Interactions of intrinsically disordered Thellungiella salsuginea dehydrins TsDHN-1 and TsDHN-2 with membranes-synergistic effects of lipid composition and temperature on secondary structure. Biochem Cell Bio. 2010;88:791-807.

43. Hundertmark M, Dimova R, Lengefeld J, Seckler R, Hincha DK. The intrinsically disordered late embryogenesis abundant protein LEA18 from Arabidopsis thaliana modulates membrane stability through binding and folding. BBA-Biomembranes. 2011;1808:446-53.

44. Borg M, Mittag T, Pawson T, Tyers M, Forman-Kay JD, Chan HS. Polyelectrostatic interactions of disordered ligands suggest a physical basis for ultrasensitivity. PNAS. 2007;104:9650-5.

45. Boucher V, Buitink J, Lin X, Boudet J, Hoekstra FA, Hundertmark M, et al. MtPM25 is an atypical hydrophobic late embryogenesis-abundant protein that dissociates cold and desiccation-aggregated proteins. Plant Cell Environ. 2010;33:418-30.

46. Tunnacliffe A, Wise MJ. The continuing conundrum of the LEA proteins. Naturwissenschaften. 2007:94:791-812

47. Clough SJ, Bent AF. Floral dip: a simplified method for agrobacteriummediated transformation of Arabidopsis thaliana. Plant J. 1998;16:735-43.

Ready to submit your research? Choose BMC and benefit from:

- fast, convenient online submission

- thorough peer review by experienced researchers in your field

- rapid publication on acceptance

- support for research data, including large and complex data types

- gold Open Access which fosters wider collaboration and increased citations

- maximum visibility for your research: over $100 \mathrm{M}$ website views per year

At $\mathrm{BMC}$, research is always in progress.

Learn more biomedcentral.com/submissions 